\title{
Forage mixed ration dairy farming - the pros and cons
}

\author{
S.L. WOODWARD, C.G. ROACH, K.A. MACDONALD and J.C. SIEMELINK \\ DairyNZ, Private Bag 3221, Hamilton \\ sharon.woodward@dairynz.co.nz
}

\begin{abstract}
The effects of legume forages on whole farm productivity and profitability (Economic Farm Surplus, EFS) were assessed for the 2006/2007 and 2007/2008 milking years in a dairy farmlet systems trial. The Control farmlet was on traditional ryegrass-white clover pastures while the Forage Mixed Ration (FMR) farmlet also included annual ryegrass, lotus, red and white clover-mix and lucerne crops. Total dry matter (DM) production was lower on the FMR farmlet than the Control due to the slow winterearly spring legume growth. Milksolids (MS) production was $9.5 \%$ higher on the FMR farmlet than the Control in $2006 / 2007$ and was $5.5 \%$ higher in 2007/2008. Most of this advantage was achieved in late summer-autumn when the FMR cows were producing $20 \%$ more milk than those on the Control due to the higher nutritional value of their diets. Higher income offset higher expenses on the FMR farmlet resulting in greater farm profitability in both years.
\end{abstract}

Keywords: dairying, Economic Farm Surplus, legumes, lotus, lucerne, milksolids, perennial ryegrass, red clover, white clover

\section{Introduction}

New Zealand's dairy industry has largely been based on perennial ryegrass (Lolium perenne L.) - white clover (Trifolium repens $\mathrm{L}$.) pastures with the inclusion of maize as a supplementary silage crop becoming more common over the last 15 years. For many years the success of a farm system was determined by the amount of dry matter (DM) grown and available to support milk production. Nowadays a whole raft of factors impact on the success of a farm system and it is likely that further profitability increases will require diversification of the industry's forage base to meet these challenges. Previous experiments have demonstrated that feeding dairy cows legume-dominant diets such as white clover (Harris et al. 1998a; Harris et al. 1997; Rogers \& Robinson 1984) and birdsfoot trefoil (lotus) (Lotus corniculatus L.) (Harris et al. 1998b; Woodward et al. 1999) increased milksolids production compared with cows fed ryegrassdominant diets. The increase occurred particularly in late summer and autumn and was due to the higher nutritional value of the legumes, the higher DM intake of cows fed legumes and the presence of condensed tannins in some legumes such as lotus. The challenge that remained was to successfully incorporate these legumes into a practical farm system and determine whether the potential production benefits occurred on-farm, and whether or not a legume-based farm system would be more profitable than the traditional ryegrass-based system.

A whole-farm systems trial designed to evaluate the effects of including high quality legumes (lotus, red (Trifolium pratense L.) and white clover mix (clover), and lucerne (Medicago sativa L.)) on DM production, milksolids (MS) production and whole (dairy) farm profitability (Economic Farm Surplus, EFS) was conducted from 2005-2008 on DairyNZ's Scott Farm near Hamilton. The trial aimed to increase per cow MS production from $360 \mathrm{~kg} \mathrm{MS} / \mathrm{cow} / \mathrm{yr}$ on the Control farmlet to $500 \mathrm{~kg} \mathrm{MS} / \mathrm{cow} / \mathrm{yr}$ on the legume-based Forage Mixed Ration (FMR) farmlet by increasing summer and autumn production and the length of lactation while still operating a profitable farm system.

\section{Methods}

\section{Trial design}

The trial was located at DairyNZ's Scott Farm near Hamilton, on a mixture of silt loam, peaty silt loam and humic silt loam soils (Stiles \& Singleton 1997). Both treatments were 9 ha farmlets with all the Control farmlet and 2 ha of the FMR farmlet located on existing ryegrasswhite clover mixed pastures. The legume crops ( 2 ha of lotus, 1.5 ha of clover mix, and 1.5 ha of lucerne) on the FMR farmlet were all established in October-November 2004 after existing pastures had been sprayed with Roundup ${ }^{\mathrm{TM}}$, cultivated, and fallowed for 4 weeks with further chemical and mechanical weed control before sowing with inoculated and treated (Superstrike ${ }^{\mathrm{TM}}$ and Gaucho $^{\mathrm{TM}}$ ) seeds using a roller drill, harrows and a final rolling. The area sown as each legume crop was initially based on predictions of DM production. Part of the lotus area was also resown in 2006/2007 ( 1 ha resown as lotus) and the remaining lotus area was resown in 2007/2008 (1 ha resown as lucerne) using the same full cultivation procedure. The annual ryegrass (Lolium multiflorum L.) in the FMR farmlet was initially established using a similar full cultivation procedure in mid-April 2006 and was then undersown with annual ryegrass in mid-April 2007 and 2008. The 2005/2006 year served as a transition year during which grazing management guidelines for the legume swards on the FMR farmlet were developed. Data presented in this paper are from the 2006/2007 and 2007/ 2008 milking years. 


\section{Cows}

Both farmlets were stocked with three multiparous Holstein-Friesian cows per hectare and were rotationally grazed. Cows were allocated to farmlets in September 2005 , so that herds were balanced for age, breeding worth, condition score, liveweight and, where available, previous MS production. In each subsequent milking year both farmlets had a $19 \%$ replacement rate.

\section{Management}

The Control farmlet operated through both years as a self-contained unit while the FMR farmlet purchased maize silage in both years. Irrigation to ensure survival of the legume crops on the FMR farmlet was permitted at a preset rate $(25 \mathrm{~mm} / \mathrm{ha}$ at each application $)$ during the summer-autumn of both years if rainfall dropped below the 10 year average for more than 4 weeks. Irrigation was not available on the ryegrass-based pastures on either farmlet. Management decisions, typical of those used on commercial, pasture-based dairy farms (Macdonald \& Penno 1998) were made to avoid compromising either the objectivity of each farmlet's management or expression of any treatment differences. These rules determined farmlet grazing rotation length, pasture silage conservation and feeding, target cow condition score and liveweight, cow dry-off, and use of bought-in maize silage supplement. The decision rules ensured that boughtin maize silage on the FMR farmlet was only fed as a supplement to maintain the condition score of dry cows at the minimum target level once pasture silage had been used up. Application rates of maintenance fertiliser were the same on both farmlets each season (potassic superphosphate $(630 \mathrm{~kg} / \mathrm{ha}$ in $2006 / 2007$ and $570 \mathrm{~kg} / \mathrm{ha}$ in $2007 / 2008)$ and lime (100 kg/ha/yr) while nitrogen (urea) fertiliser was applied across the entire Control farmlet but only on the ryegrass paddocks on the FMR farmlet (maximum, approximately $200 \mathrm{~kg} \mathrm{~N} / \mathrm{ha} / \mathrm{yr}$ ).

\section{Measurements}

Pasture growth rate $(\mathrm{kg} \mathrm{DM} / \mathrm{ha} / \mathrm{d})$ and herbage accumulation $(\mathrm{kg} \mathrm{DM} / \mathrm{ha})$ in every ryegrass-based paddock on each farmlet were derived monthly from weekly visual assessment of herbage mass, calibrated by cutting and weighing pasture samples (Eerens et al. 2001). Growth rates and herbage accumulation in the legume-based swards were derived from herbage cuts made pre- and post-grazing throughout both years. Cuts were also made pre-grazing to determine botanical composition of the legume swards.

Individual cow milk yields and milk composition were measured on 1 day per week throughout lactation and these measures were used to calculate MS yield (milkfat plus milk protein yield; $\mathrm{kg} \mathrm{MS} / \mathrm{cow}$ ). Cow liveweight and body condition score were measured weekly during lactation and fortnightly when cows were dry.

Economic farm surplus (EFS) is a measure of the profitability of a dairy farm enterprise and is widely used as an indicator of economic trends within the industry (Penno et al. 1996). It was calculated on each farmlet for both years as described by Woodward et al. (2001). Costs of inputs and expenses were based on data from a 200506 DairyBase Economic Survey of New Zealand dairy farms (DairyBase Limited 2007) when the MS payout was $\$ 4.18 / \mathrm{kg}$ MS. EFS data were calculated according to Dexcel guidelines (see Dexcel Farm Facts 7-3 2000/ 2001) and did not include the initial capital costs of establishing the farmlets.

\section{Results and Discussion}

Which farmlet grew more dry matter?

Total DM production was higher on the Control than the FMR farmlet because the legume crop yields were lower than the ryegrass pasture yields (Table 1) in both years. The legume crops had much lower growth rates than the ryegrass pastures during winter-early spring precluding grazing between mid-May and mid-October. While this had little direct effect on MS production, since cows were either dry or in early lactation when the ryegrass pastures had high nutritional value, having $55 \%$ of the farmlet unavailable for grazing during winter-early spring put additional grazing pressure on the perennial and annual ryegrass pastures. The FMR farmlet was therefore dependent on bought-in maize silage to maintain a slow grazing rotation over winter and to supplement cow pasture intake.

\section{How did the drought conditions in 2007/2008 affect dry matter production on the Control and FMR farmlets?}

Total DM production on both farmlets was lower in 2007/2008 than 2006/2007 (Table 1) due to drought conditions prevailing during January to mid-April 2008 when rainfall was only $20 \%$ of the 10 -year average. Growth rates of the perennial ryegrass pastures in March 2008, for example, averaged 2 and $9 \mathrm{~kg} \mathrm{DM} / \mathrm{d}$ on the Control and FMR farmlets, respectively, compared with 70 and $72 \mathrm{~kg} \mathrm{DM} / \mathrm{d}$ for the same farmlets in the previous year. The effects of the drought were comparatively greater on the Control farmlet since the legume crops, particularly the lucerne, suffered a comparatively smaller decrease in yield during the dry conditions than the ryegrass-based pasture. During March 2008, for example, the lucerne grew $53 \mathrm{~kg} \mathrm{DM} / \mathrm{ha} / \mathrm{d}$. Lucerne is classed as a drought resistant species (Frame et al. 1998) due to its well developed tap root, high water-use efficiency (WUE) and ability of the plant to become semi-dormant under severe drought conditions (Woodward \& Sheehy 1979). The legume crops received irrigation $(25 \mathrm{~mm}$ per 
Table 1 Total DM production, silage conserved (ryegrass pasture and legume crop) and total silage fed (ryegrass and legume silage made on-farm plus bought-in maize silage) on the Control and FMR farmlets in 2006/2007 and 2007/2008.

\begin{tabular}{ccccc}
\hline & \multicolumn{2}{c}{$2006 / 2007$} & \multicolumn{2}{c}{$2007 / 2008$} \\
& Control & FMR & Control & FMR \\
\hline Total DM production (t DM/ha/yr) & 22.0 & 16.7 & 15.4 & 14.3 \\
Perennial ryegrass (t DM/ha/yr) & 22.0 & 21.6 & 15.4 & 16.1 \\
Annual ryegrass (t DM/ha/yr) & & 20.6 & & 17.0 \\
Lotus (t DM/ha/yr) & & 12.3 & & 10.5 \\
Clover mix (t DM/ha/yr) & & 11.0 & & 10.2 \\
Lucerne (t DM/ha/yr) & 602 & 16.4 & 764 & 15.2 \\
Total silage made (kg DM/cow/yr) & 436 & 531 & 930 & 395 \\
Total silage used (kg DM/cow/yr) & & 342 & & 850 \\
Maize silage bought-in (kg DM/cow/yr) & & & 455 \\
\hline
\end{tabular}

Table 2 Lactation length, milk production, milk composition, milksolids production, liveweight and body condition score at drying-off on the Control and FMR farmlets in 2006/2007 and 2007/2008.

\begin{tabular}{lcccc}
\hline & \multicolumn{2}{c}{$2006 / 2007$} & \multicolumn{2}{c}{$2007 / 2008$} \\
& Control & FMR & Control & FMR \\
\hline Days in milk (DIM) & 270 & 277 & 230 & 233 \\
Milk (kg/cow/yr) & 5009 & 5600 & 4301 & 4727 \\
Fat concentration (\%) & 4.76 & 4.58 & 4.63 & 4.50 \\
Protein concentration (\%) & 3.70 & 3.67 & 3.57 & 3.55 \\
Milksolids (kg/cow/yr) & 412 & 451 & 346 & 365 \\
Milksolids (kg/ha/yr) & 1236 & 1353 & 1038 & 1095 \\
Liveweight at drying off (kg/cow) & 519 & 520 & 498 & 500 \\
Body condition score (BCS) at drying off & 4.1 & 4.2 & 3.7 & 3.9 \\
\hline
\end{tabular}

Table 3 Economic Farm Surplus (EFS) calculations (\$ per hectare) on the Control and FMR farmlets in 2006/ 2007 and 2007/2008. Animal expenses include cow health costs, including bloat drench, CIDR costs and breeding and herd testing expenses. Feed expenses include silage making ( $\$ 0.15 / \mathrm{kg} \mathrm{DM})$, purchasing silage $(\$ 0.24 / \mathrm{kg} D M)$, costs associated with rearing replacement stock off-farm, maintenance and nitrogen fertiliser costs, costs associated with renewing pastures (full cultivation @ $\$ 765 /$ ha, undersowing @ \$96/ha), weed and pest control costs, and irrigation costs (\$55/ha per application). Other expenses include shed expenses, vehicle expenses, costs for repairs and maintenance, electricity, freight, administration and depreciation.

\begin{tabular}{lcccc}
\hline & \multicolumn{2}{c}{$2006 / 2007$} & \multicolumn{2}{c}{$2007 / 2008$} \\
& Control & FMR & Control & FMR \\
\hline Total Income & 5542 & 5932 & 4615 & 4853 \\
Total Expenses & 3003 & 3075 & 3194 & 3318 \\
EFS & 2539 & 2856 & 1421 & 1535 \\
Milksolids income ( \$4.18/kg MS) & 5166 & 5656 & 4339 & 4577 \\
Labour Expenses & 459 & 468 & 459 & 468 \\
Animal Expenses & 262 & 312 & 262 & 304 \\
Feed Expenses & 1038 & 1048 & 1250 & 1322 \\
$\quad$ Silage making & 271 & 85 & 344 & 178 \\
$\quad$ Maize silage purchased & 0 & 246 & 0 & 328 \\
$\quad$ Grazing replacements & 222 & 222 & 222 & 222 \\
$\quad$ Maintenance fertiliser & 198 & 198 & 180 & 180 \\
$\quad$ Nitrogen fertiliser & 308 & 137 & 279 & 95 \\
$\quad$ Pasture renewal & 11 & 117 & 96 & 128 \\
$\quad$ Weed and pest control & 29 & 43 & 29 & 38 \\
$\quad$ Irrigation & 0 & 0 & 0 & 153 \\
Other Expenses & 1244 & 1247 & 1223 & 1224 \\
\hline
\end{tabular}


Figure 1 Milksolids production per cow during 2006/2007 and 2007/2008 for the Control ( $\bullet$ ) and FMR ( O ) farmlets.
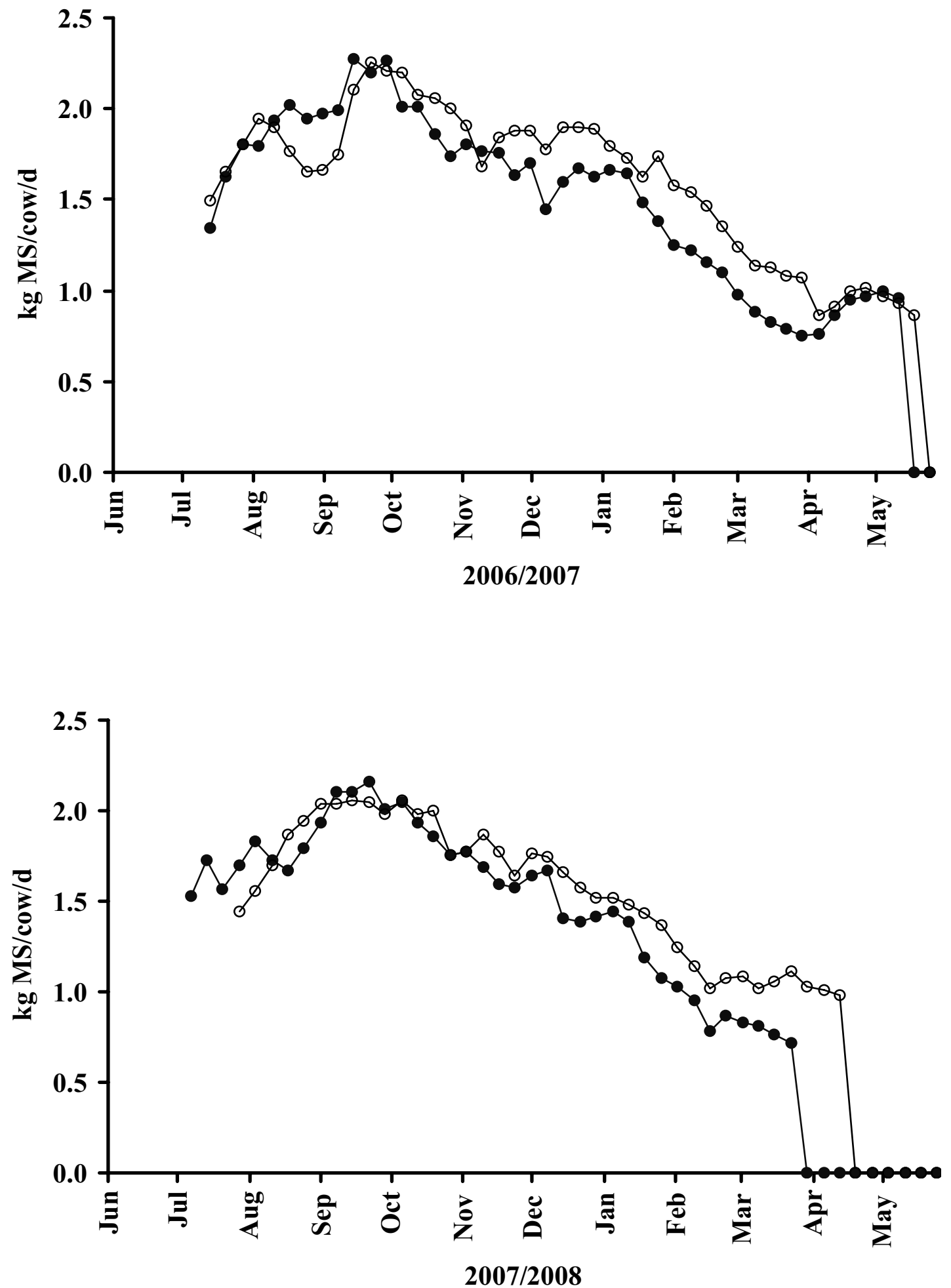
application with five applications on each crop) during the 2007/2008 summer-autumn drought that also contributed to the higher growth rates of the legume crops and ensured their survival during the 2007/2008 summer-autumn drought but only amounted to a small operating cost on the FMR farmlet (\$153/ha) (Table 3).

\section{Did the FMR farmlet have higher milksolids production?}

MS production per cow and per hectare was $9.5 \%$ higher on the FMR farmlet than the Control farmlet in 2006/ 2007 and 5.5\% higher in 2007/2008 (Table 2). As expected, most of this advantage was achieved in late summer-autumn (Fig. 1) when cows in the FMR herd were producing $20 \%$ more milk than the Control cows due to the higher nutritional value of their diets which were at least $50 \%$ legume-based. There was little difference in lactation length between the two farmlets although in 2006/2007 the FMR cows milked for 1 week longer and for 3 weeks longer in 2007/2008 but a later calving date for the FMR herd in 2007/2008 meant there was little difference in days in milk (Table 2). Unfortunately, in the 2007/2008 year, there was limited opportunity for the FMR farmlet to display much advantage in late summer-autumn production as the FMR cows were dried off early (11 April 2008). At this time, the FMR cows were producing $0.98 \mathrm{~kg} \mathrm{MS} /$ cow $/ \mathrm{d}$ (Fig. 1 ), which was higher than the drying-off target (less than $0.5 \mathrm{~kg} \mathrm{MS} / \mathrm{cow} / \mathrm{d}$ for 2 consecutive weeks (Macdonald \& Penno 1998)), but the body condition score of some cows was approaching the critical level for drying-off (3.5 for cows and heifers at the start of April (Macdonald \& Penno 1998)) and there was insufficient feed due to drought to continue feeding milking cows.

\section{Was there a difference in the profitability of the Control and FMR farmlets?}

In both years, the FMR farmlet was more profitable than the Control farmlet (Table 3). Total expenses were slightly higher on the FMR farmlet in both years. While the cost of harvesting pasture silage on the FMR farmlet was about half that on the Control farmlet, total silage expenses were greater due to the cost of bought-in maize silage. The non-application of nitrogen fertiliser to legume crops meant nitrogen fertiliser use per hectare on the FMR farmlet was much lower than on the Control farmlet in both seasons but there was no difference in maintenance fertiliser expenses. Some renewing of selected legume crops was undertaken in each season but the cost of this was small per hectare since only a small proportion of the FMR farmlet was resown. In contrast, all of the Control farmlet had to be undersown with perennial ryegrass in autumn 2007/2008 due to drought-damage to ryegrass pastures. This resulted in a higher cost than on the FMR farmlet where the legume crops tolerated the drought conditions better and only 4 ha of ryegrass (annual and perennial) was undersown. The FMR farmlet incurred extra expenses to cover bloat drenching of the cows grazing legume pastures, irrigation (mainly due to electricity costs), the greater need for weed spraying of the legume crops compared with weed control of ryegrass-based pastures. In both years, the additional income on the FMR farmlet from extra MS production offset the higher expenses (Table 3), even in drought affected 2007/2008 when cows were dried-off earlier than expected.

\section{Summary}

The findings of this study suggest that including high nutritive value legume forages on-farm did have a positive effect on MS production and might be profitable. The findings should be viewed with some caution, however, since the trial lasted for only two complete milking years. It is also worth noting that the increase in MS production on the FMR farmlet was less than could have been expected based on previous short-term experiments where legume-based diets were fed to dairy cows (Harris et al. 1998a; Woodward et al. 1999) and the $500 \mathrm{~kg} \mathrm{MS} / \mathrm{cow} /$ yr target was not achieved in either year. This was due to the lower DM yield potential of the legume crops compared with the ryegrass-based pastures that restricted the legumes to a maximum of $50 \%$ of the cows' daily intake at any stage of the season. The poor persistence of some legume crops, especially the lotus and red clover, also meant loss of potential DM production when crops had to be resown and contributed to higher costs. Despite these disadvantages of legumes, previous short-term experiments suggest that including legume forages such as lotus on-farm will also offer environmental benefits such as reduced methane emissions (Woodward et al. 2004) and a greater proportion of nitrogen losses from the cow being partitioned into faeces than urine ( $\mathrm{S}$. Woodward pers. comm.). While the EFS calculations presented in this paper do not include any monetary value for environmental benefits or costs, it is likely that the changing face of the dairy industry will mean that such environmental effects will soon have an important impact on the economics of dairy farming. The increase in MS payout along with increased costs, particularly those associated with nitrogen fertiliser, by the end of the 2007/ 2008 year also tend to improve the profitability (EFS) of the FMR farmlet more than the Control farmlet.

\section{ACKNOWLEDGEMENTS}

This research was fully funded by DairyNZ (previously Dairy Insight). The authors thank DairyNZ Field Technicians and Scott Farm Staff for their assistance 
with weekly farmwalks and running of the trial. And also thanks to Jim Lancaster, Carol Leydon-Davis and Barbara Dow for their assistance with data collection and advice.

\section{REFERENCES}

DairyBase Limited. 2007. 2005-06 DairyBase Economic Survey. 52 pp.

Dexcel Farm Facts. 2000/2001. Economic Farm Surplus. Dexcel Farm Facts No. 7-3. 4 pp. Dexcel Limited. 2003.

Eerens, J.P.J.; Crush, J.R.; Woodward, S.L.; Macdonald, K.A.; Carter, W.A. 2001. Milksolids production from different combinations of perennial ryegrass and white clover cultivars: I. Trial design, farmlet management, and pasture performance. Proceedings of the New Zealand Grassland Association 63: 91-96.

Frame, J.; Charlton, J.F.L.; Laidlaw, A.S. 1998. Temperate forage legumes. CAB International, 198 Madison Avenue, New York, NY, USA. 327 pp.

Harris, S.L.; Auldist, M.J.; Clark, D.A.; Jansen, E.B.L. 1998a. Effects of white clover content in the diet on herbage intake, milk production and milk composition of New Zealand dairy cows housed indoors. Journal of Dairy Research 65: 389-400.

Harris, S.L.; Clark, D.A.; Auldist, M.J.; Waugh, C.D.; Laboyrie, P.G. 1997. Optimum white clover content for dairy pastures. Proceedings of the New Zealand Grassland Association 59: 29-33.

Harris, S.L.; Clark, D.A.; Laboyrie, P.G. 1998b. Birdsfoot trefoil - an alternative legume for New Zealand dairy pastures. Proceedings of the New Zealand Grassland Association 60: 99-103.

Macdonald, K.A.; Penno, J.W. 1998. Management decision rules to optimise milksolids production on dairy farms. Proceedings of the New Zealand Society of Animal Production 58: 132-135.

Penno, J.W.; Macdonald, K.A.; Bryant, A.M. 1996. The economics of No 2 dairy systems. Proceedings of the Ruakura Farmers' Conference 48: 11-19.

Rogers, G.; Robinson, I. 1984. Whole lactation production of cows grazing white clover or perennial ryegrass. pp. 148-149. In: Dairy Production Research Report. Department of Agriculture and Rural Affairs, Australia.

Stiles, S.; Singleton, P. 1997. The distribution of soils on the AgResearch farm at Newstead. AgResearch Internal Report. 60 pp.

Woodward, F.I.; Sheehy, J.E. 1979. Microclimate, photosynthesis and growth of lucerne (Medicago sativa L.) 2. Canopy structure and growth. Annals of Botany 44: 709-719.

Woodward, S.L.; Auldist, M.J.; Laboyrie, P.J.; Jansen, E.B.L. 1999. Effect of Lotus corniculatus and condensed tannins on milk yield and milk composition of dairy cows. Proceedings of the New Zealand Society of Animal Production 59: 152-155.

Woodward, S.L.; Macdonald, K.A.; Carter, W.A.; Eerens, J.P.J.; Crush, J.R. 2001. Milksolids production from different combinations of perennial ryegrass and white clover cultivars: II Milksolids production and conclusion. Proceedings of the New Zealand Grassland Association 63: 97-102.

Woodward, S.L.; Waghorn, G.C.; Laboyrie, P.G. 2004. Condensed tannins in birdsfoot trefoil (Lotus corniculatus) reduce methane emissions from dairy cows. Proceedings of the New Zealand Society of Animal Production 64: 160-164. 